\title{
Internal market orientation, frontliners' organizational commitment and customer-oriented behavior: A study of airport service in Vietnam
}

\author{
Nguyen Thi Hong Phuong ${ }^{1}$, Le Nguyen Hau ${ }^{2 *}$, Tran Thi Tuyet ${ }^{2}$, Nguyen Van Tuan $^{2}$ \\ ${ }^{1}$ Lien Khuong Airport - Lam Dong, Vietnam \\ ${ }^{2}$ Ho Chi Minh City University of Technology, Vietnam National University HCMC, \\ Vietnam \\ *Corresponding author: Inhau@ @cmut.edu.vn
}

\begin{tabular}{ll}
\hline \multicolumn{1}{c}{ ARTICLE INFO } & \multicolumn{1}{c}{ ABSTRACT } \\
$\begin{array}{l}\text { DOI:10.46223/HCMCOUJS. } \\
\text { econ.en.8.1.167.2018 }\end{array}$ & $\begin{array}{l}\text { This research examines the three-component structure of } \\
\text { the concept internal market orientation (IMO) and investigates } \\
\text { its impact on frontliners' organizational commitment (OC) and } \\
\text { customer-oriented behavior (COB) in the context of airport }\end{array}$ \\
$\begin{array}{l}\text { Received: May } 17^{\text {th }}, 2018 \\
\text { Revised: August } 19^{\text {th }}, 2018\end{array}$ & $\begin{array}{l}\text { service in Vietnam. Based on a sample of } 294 \text { frontliners } \\
\text { Accepted: September } 16^{\text {th }}, 2018\end{array}$ \\
$\begin{array}{l}\text { Working in various airports, SEM analysis reveals that IMO has } \\
\text { a strong impact on OC. It also has direct and indirect impacts on } \\
\text { airport service, customer- } \\
\text { oriented behavior, internal } \\
\text { market orientation, } \\
\text { organizational commitment }\end{array}$ & $\begin{array}{l}\text { Structure of IMO. It is, therefore, suggested that IMO is } \\
\text { powerful to enhance both internal employee management and } \\
\text { external marketing performance in the research context. }\end{array}$
\end{tabular}

\section{Introduction}

The aviation service in Vietnam has been developing enormously during recent years. According to the International Air Transport Association (IATA, 2016), Vietnam will be among the five fastest-growing markets in terms of additional passengers per year over the 2015-2035 period. However, besides this positive signal for the market, this fast growth entails a number of challenges for service providers in the field. One of the inevitable problems is the work-load of ground-service employees at airports which negatively affect their attitude and behavior at work. This situation calls for managerial attention to ensure a highly committed workforce and good services being offered to passengers.

Marketing literature shows that the attitude and behavior of service employees have an important influence on a firm's marketing performance (Lings, 2004; Pimpakorn \& Patterson, 2010). Particularly, customers usually form their impression towards the firm based on their perception of the employees who directly provide the service on behalf of the firm. Therefore, service employees working in the front stage (i.e., service frontliners) play a very crucial role in creating customer satisfaction. Consequently, the research stream on service frontliners' attitudes and behaviors have received much attention from several researchers recently (e.g., 
Buil, Martínez, \& Matute, 2016; Plouffe, Bolander, Cote, \& Hochstein, 2016; Stock, Jong, \& Zacharias, 2017).

Literature has established that there are generally two categories of factors affecting employees' attitudes and behavior, namely organizational factors and dispositional factors (Schneider \& Smith, 2004). Within the managerial perspective, the current study focuses on exploring organizational measures to foster service frontliner's favorable behaviors of an organization's existing workforce. Among organizational measures, internal marketing has received attention from researchers and practitioners as an effective way to influence employees. Basically, internal marketing is a management philosophy viewing employees as customers of the firm (Lings \& Greenley, 2009). It promotes the idea that satisfying the wants and needs of service employees, especially frontliners, is a prerequisite to their job commitment and also ensures a good service to customers (Lings, 2004). In other words, the implementation of internal marketing in a firm, which is termed internal market orientation - IMO (Lings, 2004; Yu, Yen, Barnes, \& Huang, 2017) is a promising measure to satisfy both (internal) employees and (external) customers.

Accordingly, IMO is defined as internal information generation and dissemination in order to facilitate organizational favorable responses to satisfy employees' wants and needs (Lings, 2004). As such, it is essential that IMO facilitates favorable attitudes and behaviors of frontliners towards the firm as well as its customers. Literature has shown a number of studies to validate such role of IMO (e.g., Bae, Kim, \& Kim, 2017; Gounaris, 2006; Lings \& Greenley, 2005; Yu et al., 2017). However, the majority of these studies were conducted in developed countries. Empirical studies in emerging and Confucius countries like Vietnam have still been limited. Moreover, empirical studies specifically undertaken in airport service are scant. Therefore, an empirical study in Vietnam airport service is needed to revalidate the theory of IMO which was originated in the West. Moreover, given the airport situation in Vietnam being described above, it is necessary to answer the question if IMO is a potential solution to the aforesaid problem.

Against the above analysis, the current research is formulated with a threefold objective. First, it identifies the component structure of IMO in the specific context of airport service firms in Vietnam. Secondly, it investigates the impact of IMO on frontliner's organizational commitment (OC). Thirdly, it accesses the total (direct and indirect) effect of IMO on frontliner's customer-oriented behavior (COB). Here, $\mathrm{OC}$ is selected as a representation of a high quality relationship between an employee and the firm (Meyer, Stanley, Herscovitch, \& Topolnytsky, 2002). Similarly, COB is a proxy construct of employee marketing performance towards external customers (Kelley, 1992).

The following section presents the conceptual background and hypothesis development, which is followed by a description of the research design. Then, research results are reported and discussed. The paper ends with a concluding remark, managerial implications and limitations. 


\section{Theoretical background and hypotheses}

\section{Employee's Customer-Oriented Behavior (COB)}

In a broad view, the construct of customer orientation can be approached from firmlevel view or individual-level view. At the firm level, it is conceptualized as a set of organizational beliefs that puts the customer's interests first, besides those of other stakeholders in order to develop a long-term profitable company (Hartline, Maxham, \& McKee, 2000). At the individual level, customer orientation is defined as the willingness of individual service employees to customize the service delivery in accordance with customer's situations such as needs, problems, special circumstances (Daniel \& Darby, 1997). The current study approaches the construct from the individual level perspective which focuses on the customer- oriented behavior (COB). Particularly, COB refers to specific behaviors displayed by service frontliners during service encountersto fulfill customer-specific needs in relation to specific problems and circumstances (Winsted, 2000).

Winsted (2000) suggests that COB is a three-dimensional construct which is common in both western and eastern culture, including (1) Concern combining elements of empathy, assurance, responsiveness, authenticity as well as perceived competence, listening and dedication. (2) Civility including a variety of behaviors service personnel should express to customers. These behaviors basically relate the employees' attitude, courtesy and attention. (3) Congeniality relating to the frontline staff's positive attitudes, sunny temperament and warm personality.

\section{Internal Market Orientation (IMO)}

IMO is based on the philosophy of treating frontline employees as customers of the firm (Lings, 2004). Therefore, IMO encourages organizations to build effective relationships with employees through the commitment to producing value for its internal market (employees) much in the same way as the commitment is required to provide value for its external customers (Gounaris, 2006). Moreover, it suggests that satisfied, motivated and committed frontline employees are crucial if customers are to receive good service (Lings, 2004). To operationalize the construct, several studies have modeled IMO as a second-order reflective construct consisting of three components (Gounaris, 2006; Lings \& Greenley, 2005), namely:

Generating information pertinent to the internal market: regarding the collection of information about important attributes of jobs, the satisfaction of employees with their working conditions, internal and external factors that influence employee satisfaction, the external market, e.g., legislative changes, activities of competitors in the employee market and employment conditions with firms competing for the same employees.

Communication of information pertinent to the internal market: regarding the dissemination of information on the one hand between managers and employees in order to communicate the organization's directives to employees and on the other hand between managers from different department and hierarchical level in order to build understandings of employees' needs among managers. 
Responding to information (or responsiveness) pertinent to the internal market: regarding designing jobs, adjusting remuneration schemes, offering training and showing management consideration with regard to the employees' feedback on their needs.

\section{Organizational Commitment (OC)}

Organizational commitment refers to the emotional attachment which employees form with the organization, based on shared values and interests (Meyer \& Allen, 1997). Meyer and Allen (1991) suggest that employees remain with the organization because they are effectively attached (wants to), they are continually attached (need to) or they are normatively attached (ought to). According to Meyer and Allen (1991), employees who want to belong with the organization are more willing to exert effort on behalf of the organization than those who need to or ought to do so. Therefore, for simplicity, this study will investigate the affective dimension (want to) of the construct of employees' organizational commitment.

\section{Foundational background: Theory of social exchange}

The reasoning of the relationship between IMO and employees' attitudes and behaviors is grounded in the theory of social exchange (Emerson, 1976), which is based on an obligation to reciprocate (Cropanzano \& Mitchell, 2005). Accordingly, the social exchange theory implies that employees will display favorable attitudes and behaviors toward the organization as a way to show their appreciation to their employer for creating satisfactory working conditions. Allen and Shanock (2013) suggested that if firms are considered as being deeply concerned about their employees' interests, staff members tend to show more positive attitudes and behaviors to the organization. As a result, the current research argues that employees' perception of an enhanced level of IMO will lead them to be more committed to the organization and being more customer-oriented on delivering service to customers.

\section{Proposed hypotheses}

In this study, the unit of analysis is a frontline employee. Thus, IMO is investigated in the view of frontline employees' perceptions and proposed to enhance their attitudes and job behaviors.

IMO and OC: Having the same tenet of market orientation concept (MO) which focuses on the satisfaction and engagement of external customers, IMO is suggested in internal marketing literature to foster employee satisfaction, leading to a commitment to the organization (Berry \& Parasuraman, 1991; Khansa, Neelum, Asma, \& Samina, 2012). Lings (2004) asserts that IMO has a significant positive relationship with internal aspects of performance including employee satisfaction and employee retention. Moreover, employees who are highly satisfied with their work, supervision, co-workers, pay and acquire a high level of overall satisfaction are more likely to be committed to their organization (Karia \& Asaari, 2006). A number of empirical studies have also provided evidence to support a positive relationship between IMO and organizational commitment via employee satisfaction (e.g., José, Bermúdez-González, Rodríguez-Molina, \& Blanca, 2014; Yu et al., 2017). Therefore, applying this thread of analysis to the case of service frontliners at airports, it is hypothesized that: 
H1: Internal market orientation has a positive relationship with airport frontliners' organizational commitment

IMO and COB: The adoption of IMO may encourage employees to enact firms' marketing strategies and incorporate this into their normal in-role behaviors in their day-to- day work. Therefore, focusing on employees' wants and needs impacts their behaviors toward the market. That is, IMO plays an important role in enhancing the good relationship between employees and customers, which leads to ensuring service quality, customers' satisfaction and financial performance (Lings \& Greenley, 2005). As mentioned before, the rationale is implied in the concept of exchange between employees and the organization in which employees evaluate the jobs by comparing the inputs (time, effort, loyalty, etc.) and the outputs (pay, benefits, recognition, status, etc.). Behaviors of managers concerning rewards employees should receive have an impact on employee's behaviors and attitudes and organizational effectiveness (Freedman \& Montanari, 1980; Guest \& Conway, 2002). Meanwhile, IMO aims to create a balance between employees' perceptions of what they put into their job and their perceptions of what they get out of the job (Lings \& Greenley, 2005). Applying this general analysis to this research context of airport service, it is argued that IMO encourages employees to behave in a customer-oriented manner. Therefore, the hypothesis states as follow

H2: Internal market orientation has a positive relationship with airport frontliners' customer-oriented behaviors

OC and COB: Several researchers have suggested that organizational commitment has impacts on employees' behaviors and performance (Finegan, 2000; Meyer, Allen, \& Smith, 1993). That is, a committed employee is willing to exert considerable and sustained personal effort to meet organizational goals, comply with organizational values (Bansal, Mendelson, \& Sharma, 2001) and to satisfy customer (Lanjananda \& Patterson, 2009). Applying this notion to the case of frontliners in airports, their main missions are to undertake the service process in interaction with customers and to serve them to the satisfactory level. Referring to the abovementioned literature review, their efforts to satisfy customers is reflected in their COB. Therefore, it is argued in this study of airport service that when a frontline employee is committed to the organization, she is more willing to work in a customer-centric manner when delivering the service on behalf of the organization. Therefore, it is hypothesized:

H3: Organizational commitment has a positive relationship with airport frontliners' customer-oriented behaviors

The research model illustrating the three proposed hypotheses is presented in figure 1 . Accordingly, IMO is proposed as a second-order formative construct composing of information generation, information sharing and responsiveness, whereas employee commitment and employee's COB are unidimensional constructs. The operationalization of IMO as a second-order formative construct facilitates the investigation of the component structure of this high-order construct in the context of airport service in Vietnam.

\section{Method}

The research setting is the airport service in Vietnam. As mentioned in the beginning, 
in the past decade, together with the development of Vietnam's economy, the number of passengers using domestic airports has risen at a fast speed. This makes the aviation market in Vietnam is among the five most fast-growing markets in the world (IATA, 2016). As a result, frontliners are often busy taking good care of all passengers. Moreover, the long-standing "asking - giving" practice in which public service providers think that they are giving service to passengers, not serving passengers still exists to a certain extent. As a result, frontliners in domestic airports are supposed to display COB to a varying degree during service encounters.

In this setting, customer-contact employees consist of airport service staff who provide passengers with a variety of tasks including parking and baggage help, information help, checkin and screening staff, security check. Accordingly, the proposed model and hypotheses were tested using survey data obtained from frontline employees at three airports in Vietnam namely, Lien Khuong (Lam Dong); Phu Bai (Hue); Cam Ranh (Khanh Hoa). These airports were selected conveniently based on their willingness to participate in the survey. Additionally, in the mentioned airports, all tasks of ground services offered to passengers are provided by frontline employees of one organization, while in big airports like Tan Son Nhat or Noi Bai, some of the tasks or services are carried out by staff from different organizations, including airline staff.

The sample comprised 294 cases surveyed from frontline airport staff. Data were obtained by means of a structured questionnairedirectly delivered and collected at these airports by a survey team of trained people, and were led by one of the authors who is the director of one of the airports. A convenience sampling technique was employed.

In terms of measurement scale (see Table 2), three reflective components of internal market orientation (IMO) namely Information Generation (5 items), Information Dissemination (4 items), Responsiveness (4 items) were measured by total 13 reflective items adopted from Lings and Greenley (2005). Employee Organizational Commitment (OC) was measured by 4 reflective items adopted from Meyer and Allen (1991). Employee's COB was measured by 5 items borrowing from Pimpakorn and Patterson (2010). The scale items were translated into Vietnamese language and checked carefully by two bilingual university faculties. All scales were in the form of Likert type anchoring from 1 (totally disagree) to 5 (totally agree).

\section{Results and discussion}

The sample characteristics are summarized in Table 1 which indicates that the sample structure was reasonably diverse in terms of gender, age group, work experience, and education level.

\section{Table 1}

Sample characteristics $(\mathrm{N}=294)$

\begin{tabular}{|l|l|l|l|l|l|l|}
\hline \multicolumn{1}{|c|}{ Variable } & Frequency & $\%$ & & Variable & Frequency & $\%$ \\
\cline { 1 - 1 } Gender: & & Education: \\
\hline
\end{tabular}




\begin{tabular}{|c|c|c|c|c|c|}
\hline Male & 168 & 57.1 & High school/College & 54 & 18.4 \\
\hline Female & 126 & 42.9 & University or higher & 240 & 81.6 \\
\hline \multicolumn{3}{|l|}{ Work Experience: } & Age group: & & \\
\hline Under 2 years & 66 & 22.4 & 30 or under & 132 & 44.9 \\
\hline 2 - under 4 yrs & 92 & 31.3 & $31-40$ & 124 & 42.2 \\
\hline 4 - under 8 yrs & 40 & 13.6 & 41 or more & 38 & 12.9 \\
\hline 8 - under 15 yrs & 66 & 22.4 & & & \\
\hline 15 yrs or more & 30 & 10.2 & & & \\
\hline
\end{tabular}

Source: The researcher's data analysis

\section{Validity and reliability of measures}

Firstly, an exploratory factor analysis (EFA) was applied to all scales together for a preliminary assessment of scales. The result indicated that the factor structure fully matched the design and each item loaded mainly on its designated factor. Next, the 22 items measuring five first-order constructs were submitted to confirmatory factor analysis (CFA) using AMOS software (Arbuckle \& Wothke, 1999) to assess the measurement model. The kurtosis values of all variables were within -0.46 to +1.97 and skewness values ranged from -1.10 to -0.14 . Although the data exhibited slight deviations from a normal distribution, it was appropriate for maximum likelihood (ML) estimation to be applied (Kline, 2015).

\section{Table 2}

Scale items and standardized loadings

\begin{tabular}{|l|c|}
\hline \multicolumn{1}{|c|}{ Item key words } & $\begin{array}{c}\text { Std. } \\
\text { loadings }\end{array}$ \\
\hline Information Generation (CR=0.79; AVE=0.55) & Eliminated \\
The airport surveys employees to access our perceived quality of employment. & 0.74 \\
Management meet with employees to find out their expectations & 0.74 \\
Management interacts directly with employees to find out ways to satisfy them. \\
Management finds out employees' true feelings in daily conversations. & 0.76 \\
When any employee acts differently, management will find out if there is a problem. & Eliminated \\
\hline Information Dissemination (CR=0.78; AVE=0.55) & \\
The airport hold regular staff meetings & 0.73 \\
Departments have regular staff meetings & 0.74 \\
The airport issues regular written reports and memos & 0.74 \\
The airport has its own website and email system updating regularly & Eliminated \\
\hline
\end{tabular}




\begin{tabular}{|l|c|}
\hline \multicolumn{1}{|c|}{ Item key words } & $\begin{array}{c}\text { Std. } \\
\text { loadings }\end{array}$ \\
\hline Responsiveness (CR=0.80; AVE=0.57) & 0.77 \\
Income is closely tied to qualifications and performance. & 0.80 \\
The airport make changes when employees are dissatisfied with the job. & Eliminated \\
The departments make concerted efforts to modify conditions of employment. & 0.69 \\
When employees are unhappy, managers and supervisors take corrective action. & \\
\hline Employee Commitment (CR=0.81; AVE=0.58) & 0.70 \\
I would be very happy to spend the rest of my career with this & 0.80 \\
airport. I really feel as if this airport's problems are my own. & 0.79 \\
This airport has a great deal of personal meaning for me. & Eliminated \\
I feel a strong sense of “belonging” to my airport. & \\
\hline Employee's Customer-oriented Behavior (CR=0.77; AVE=0.53) & 0.71 \\
I am available when passengers need me. & Eliminated \\
I provide excellent solutions to passengers' needs. & 0.74 \\
I respect passengers at all times. & Eliminated \\
I always behave in a professional manner. & \\
I always listen to passengers. &
\end{tabular}

Source: The researcher's data analysis

Refinement was made by eliminating 7 items (see Table 2) due to low loading or high covariance of error terms. Finally, CFA of the measurement model which included the remaining 15 items yielded the following measures: Chi-square $\chi^{2}(\mathrm{df}=80)=201.20 ; \mathrm{p}<0.05$; Normed chi-square $\chi 2 / \mathrm{df}=2.52$; Goodness-of-fit index GFI $=0.92$; Tucker- Lewis index TLI $=0.91$; Comparative fitindex $\mathrm{CFI}=0.93$; Root mean square error of approximation RMSEA $=$ 0.07. It was also noted that no offending estimates were found (i.e., no negative error variances or Heywood cases) (Hair, Black, Babin, \& Anderson, 2010). All these statistics showed that the measurement model fits the data set in this empirical study.

As shown in Table 2, all item loadings on their designate constructs range from 0.69 to 0.80 and AVE of scales ranged from 0.53 to 0.58 , which were all above 0.50 , indicating satisfactory convergent validity. Correlation coefficients between pairs of constructs ranged from 0.36 to 0.72 . The squares of which were from 0.13 to 0.53 , indicating the discriminant validity of scales. Composite reliabilities were from 0.77 to 0.81 . Thus, convergent validity, discriminant validity and reliability of scales are satisfactory.

Given the satisfactory fit of the measurement model, the proposed hypotheses were then tested using structural equation modeling (Figure 1). The estimation of the proposed structural model using ML method resulted in a good fit: Chi-square $=203.22 ; \mathrm{dF}=82 ; \mathrm{CFI}=0.920$; GFI $=0.904 ; \mathrm{TLI}=0.902 ; \mathrm{RMSEA}=0.076$. 
Based on the standardized path coefficients being shown in Table 3, three hypotheses $\mathrm{H} 1, \mathrm{H} 2$ and $\mathrm{H} 3$ were supported (at $\mathrm{p}<0.05$ ). In other words, internal market orientation has significantly positive direct effects on employee's organizational commitment $(\beta=0.65$ $\mathrm{p}=0.005)$ and employee's customer-oriented behavior $(\beta=0.28 \quad \mathrm{p}=0.017)$. Employee's organizational commitment then has a positive effect on employee's customer-oriented behavior $(\beta=0.33 \mathrm{p}=0.023)$. The results also showed that the proportion of the variance in employee's commitment explained by the internal market orientation was at $42 \%$ and that of customer-oriented behavior was at $31 \%$.

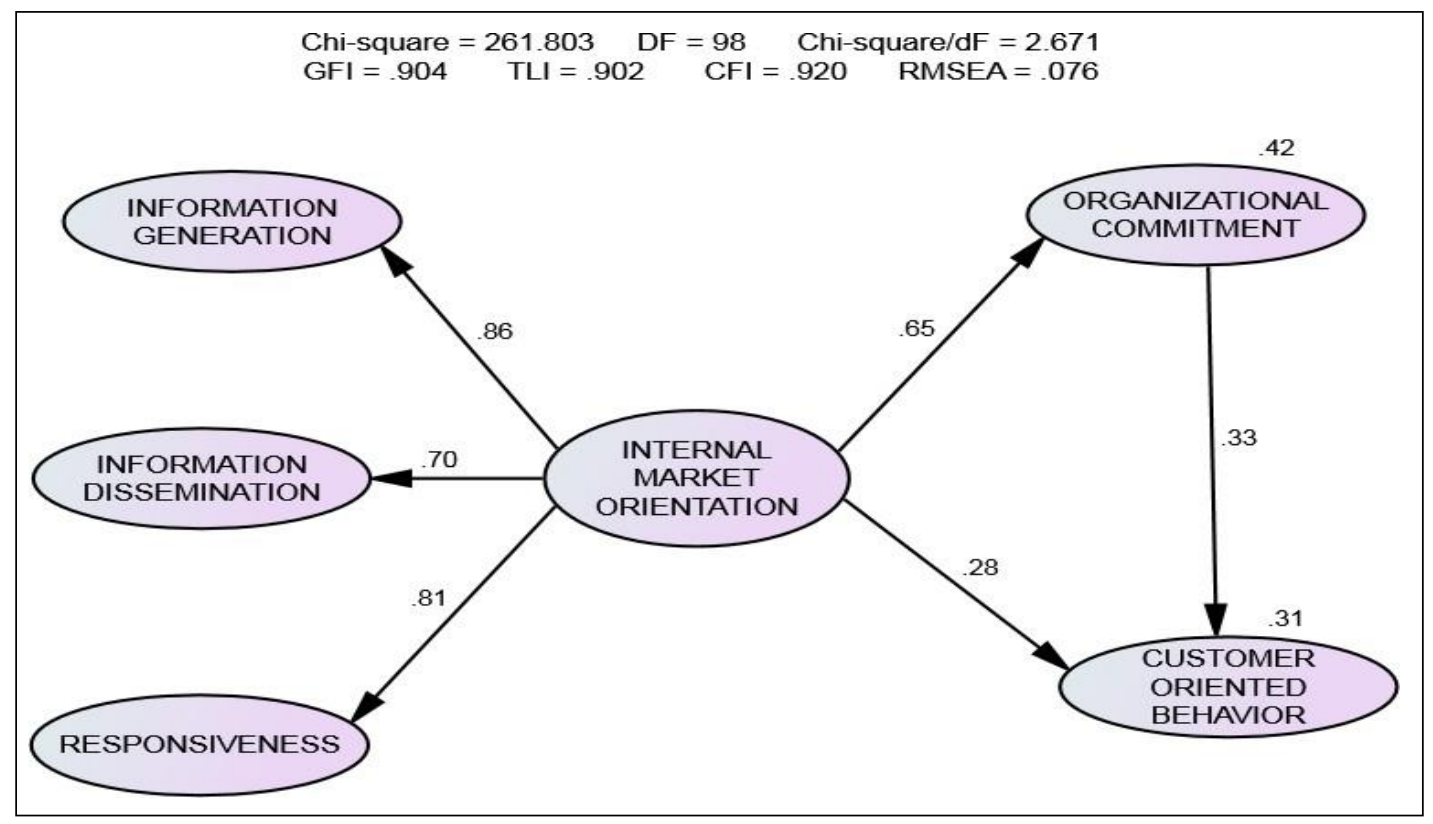

Figure 1. Result of Structural Model Estimation

\section{Table 3}

AMOS estimation results

\begin{tabular}{|c|c|c|c|c|}
\hline & Path & $\begin{array}{l}\text { Std. } \\
\text { Coeff. }\end{array}$ & $\begin{array}{c}\text { p } \\
\text { value }\end{array}$ & $\begin{array}{c}\text { Hypothesis } \\
\text { test }\end{array}$ \\
\hline 1 & Internal Market Orientation $\rightarrow$ Employee Commitment & 0.65 & 0.005 & Support H1 \\
\hline 2 & Internal Market Orientation $\rightarrow$ Customer-Oriented Behavior & 0.28 & 0.017 & Support H2 \\
\hline 3 & Employee Commitment $\rightarrow$ Customer-Oriented Behavior & 0.33 & 0.023 & Support H3 \\
\hline & Internal Market Orientation $\rightarrow$ Information Generation & 0.86 & 0.005 & \multirow{3}{*}{$\begin{array}{c}\text { Three } \\
\text { reflective } \\
\text { components }\end{array}$} \\
\hline & Internal Market Orientation $\rightarrow$ Information Dissemination & 0.70 & 0.005 & \\
\hline & Internal Market Orientation $\rightarrow$ Responsiveness & 0.81 & 0.004 & \\
\hline
\end{tabular}

Source: Data analysis result of the research 


\section{Testing the mediating effect of employee's organizational commitment}

Moreover, as shown in Table 4, internal market orientation has both a direct and indirect effect on employee's customer-oriented behavior. Internal market orientation was found to have significant direct effect $(\beta=0.28 ; p=0.017)$ and indirect effect $(\beta=0.22 ; p=0.020)$, so the standardized total effect is $0.50(\mathrm{p}=0.003)$. Therefore, the employee's organizational commitment plays a partial mediating role in the relationship between IMO and COB.

\section{Table 4}

Testing the mediating effect of employee commitment

\begin{tabular}{|ccc|c|c|c|c|c|c|l|}
\hline \multicolumn{2}{|c|}{ Effect } & \multicolumn{2}{c|}{ Direct } & \multicolumn{2}{c|}{ Indirect } & \multicolumn{2}{c|}{ Total } & \multirow{2}{*}{ Mediating Test } \\
\cline { 3 - 10 } Path & & $\begin{array}{c}\text { Std. } \\
\text { Coeff }\end{array}$ & $\mathrm{p}$ & $\begin{array}{c}\text { Std. } \\
\text { Coeff }\end{array}$ & $\mathrm{p}$ & $\begin{array}{c}\text { Std. } \\
\text { Coeff }\end{array}$ & $\mathrm{p}$ & \\
\hline $\mathrm{IMO}$ & $\rightarrow$ & OC & 0.65 & 0.004 & - & - & 0.65 & 0.004 & \\
\hline OC & $\rightarrow$ & COB & 0.33 & 0.023 & - & - & 0.33 & 0.023 & \\
\hline IMO & $\rightarrow$ & COB & 0.28 & 0.017 & 0.22 & 0.020 & 0.50 & 0.003 & Partial mediation \\
\hline
\end{tabular}

Source: The researcher's data analysis

\section{Discussion and conclusion}

The current study is context-specific research which tests the role and applicability of the concept IMO in the airport service in Vietnam. It firstly provides empirical evidence on the component structure of IMO in this specific context. Accordingly, IMO has three reflective components, i.e., information generation $(\lambda=0.86 \mathrm{p}=0.005)$, information dissemination $(\lambda=0.70$ $\mathrm{p}=0.005)$ and responsiveness $(\lambda=0.81 \mathrm{p}=0.004)$. Therefore, it can be concluded that in the context of airport service in Vietnam, IMO is a second-order construct consisting of three firstorder reflective components, namely information generation, information dissemination, and responsiveness. This result provides empirical evidence to support the original structure of IMO as proposed by Lings and Greenley (2005). Moreover, it further supports the structure of the external market orientation concept (MO) as initiated by Kohli and Jarworski (1990).

The second finding consolidates the importance of IMO in strengthening employee commitment to the airport. With the high impact of IMO on organizational commitment, it is proved to be an effective managerial measure in human resource management at airports in Vietnam to develop a strong bond between the firm and its workforce. In as much as the same way firms treat their customers, this principle which was originated in external marketing can work well in the relationship between a firm and its employees.

The third finding shows that in this specific context, IMO has a substantial total effect on employee's external marketing performance, which is represented by the concept of customer-oriented behavior, an important prerequisite of customer satisfaction. By its significant direct and indirect effects (via organizational commitment), IMO is proved to be an effective 
tool if an airport is to provide good services to its passengers and to be more market-oriented.

The findings also bring about two managerial implications for airport services in Vietnam. First, it is suggested that airport managers should put primary emphasis on internal market orientation programs (IMO) to achieve success for the organizations. Airport managers should maintain frequently the internal communication activities; being patient and willing to listen to their subordinates' ideas and problems in order to give them timely responses or adjustments in the policies of the company. Informal daily conversations between airport managers and staff also seem to be a powerful tool to find out employees' expectations.

Second, since organizational commitment (OC) plays an important role in determining customer-orientated behavior (COB), it should be given more emphasis. This result leads to a suggestion that airport managers should emphasize building a loyal relationship with employees by treating them as customers of the firms. Airport managers should motivate their employees and make them realize that they are an invaluable asset to the firm. In addition to the suggestions described above, it is imperative that employees are compensated with the salary which is worth their efforts devoted to the organization. It is also good to note the importance of other rewards such as gratitude and appreciation from managers. Employees are more likely to attach to and remain with the organization if they find their complete compensation package as being fair and acceptable (Sohail \& Jang, 2017).

In conclusion, this study is to validate and then to promote the concept of internal market orientation that its implementation in airports is powerful to enhance the effectiveness of both internal human resource management and external marketing performance. It hastested the relationship between internal market orientation, employee organizational commitment and employee customer-oriented behavior. The results from data analysis show that IMO has a strong positive impact on employees' commitment which then has a considerable positive impact on COB. IMO also has a significantly positive direct relationship with employees' COB. Theoretically, these findings contribute to enrich the body of knowledge of IMO's role in employee management and firm's marketing performance. It also demonstrates that similar to the case of its original construct of market orientation, the three-component structure of IMO can be applicable across countries and industries. Thus, it is expected that IMO and its sibling concept MO can be applicable worldwide.

The study inevitably has some limitations. First, the sample which was drawn from 3 out of 22 airports in Vietnam has limited the generalizability of the findings. Further research should revalidate the findings in other airport settings. Moreover, IMO and organizational commitment can only explain $31 \%$ of the variance of COB. There must be other determinants of the construct which need to be uncovered.

\section{References}

Allen, D. G., \& Shanock, L. R. (2013). Perceived organizational support and embeddedness as key mechanisms connecting socialization tactics to commitment and turnover among new employees. Journal of Organizational Behavior, 34(3), 350-369. doi:10.1002/job.1805 
Arbuckle, J. L., \& Wothke, W. (1999). AMOS 4.0 user's guide. Chicago, IL: Small Waters Corporation.

Bae, S. Y., Kim, J., \& Kim, G. L. (2017). Effect of internal marketing on customer orientation and business performance will, and mediating effect of market orientation in small-tomedium sized hospitals. Journal of Health Informatics and Statistics, 42(1), 44-52. doi:10.21032/jhis.2017.42.1.44

Bansal, H. S., Mendelson, M. B., \& Sharma, B. (2001). The impact of internal marketing activities on external marketing outcomes. Journal of Quality Management, 6(1), 61-76. doi:10.1016/S1084-8568(01)00029-3

Berry, L. L., \& Parasuraman, A. (1991). Marketing services, competing through quality. New York, NY: Free Press, Toronto, Canada: Maxwell Macmillan Canada, New York, NY: Maxwell Macmillan International.

Buil, I., Martínez, E., \& Matute, J. (2016). From internal brand management to organizational citizenship behaviors: Evidence from frontline employees in the hotel industry. Tourism Management, 57, 256-271. doi:10.1016/j.tourman.2016.06.009

Cropanzano, R., \& Mitchell, M. (2005). Social exchange theory: An interdisciplinary review. Journal of Management, 31(6), 874-900. doi:10.1177/0149206305279602

Daniel, K., \& Darby, D. (1997). Factors that influence nurses' customer orientation. Journal of Nursing Management, 7(5), 271-281. doi:10.1046/j.1365-2834.1999.00129.x

Emerson, R. M. (1976). Social exchange theory. Annual Review of Sociology, 2(1), 335-362.

Finegan, J. E. (2000). The impact or person and organizational values on organizational commitment. Journal of Occupational and Organizational Psychology, 73(2), 149-169. doi:10.1348/096317900166958

Freedman, S. M., \& Montanari, J. R. (1980). An integrative model of managerial reward allocation. The Academy of Management Review, 5(3), 381-390.

Gounaris, S. (2006). Internal market orientation and its measurement. Journal of Business Research, 59(4), 432-448. doi:10.1016/j.jbusres.2005.10.003

Guest, D. E., \& Conway, N. (2002). Communicating the psychological contract: An employer perspective. Human Resource Management Journal, 12(2), 22-38. doi:10.1111/j.17488583.2002.tb00062.x

Hair, J. F., Black, W. C., Babin, B. J., \& Anderson, R. E (2010). Multivariate data analysis. Upper Saddle River, New Jersey: Prentice Hall.

Hartline, M., Maxham, J., \& McKee, D. (2000). Corridors of influence in the dissemination of customer-oriented strategy to customer contact service employees. Journal of Marketing, 64(2), 35-50.

IATA. (2016). IATA Forecasts passenger demand to double over 20 years. Retrieved April 20, 2018, from http://www.iata.org/pressroom/pr/Pages/2016-10-18-02.aspx 
José, L. R., Bermúdez-González, G., Rodríguez-Molina, M. A., \& Blanca, M. J. (2014). Internal market orientation: An empirical research in hotel sector. International Journal of Hospitality Management, 38, 11-19. doi:10.1016/j.ijhm.2013.12.002

Karia, N., \& Asaari, M. H. (2006). The effects of total quality management practices on employees' work-related attitudes. The TQM Magazine, 18(1), 30-43. doi:10.1108/09544780610637677

Kelley, S. W. (1992). Developing customer orientation among service employees. Journal of the Academy of Marketing Science, 20(1), 27-36. doi:10.1007/BF02723473

Khansa, Z., Neelum, J., Asma, A., \& Samina, B. (2012). Impact of internal marketing on market orientation and business performance. International Journal of Business and Social Science, 3(12), 77-87.

Kline, R. B. (2015). Principles and practice of structural equation modeling. New York, NY: The Guilford Press.

Kohli, A., \& Jarworski, B. (1990). Market orientation: The construct, research propositions, and managerial implications. Journal of Marketing, 54(2), 1-18. doi:10.2307/1251866

Lanjananda, P., \& Patterson, P. G. (2009). Determinants of customer-oriented behavior in a health care context. Journal of Service Management, 20(1), 5-32. doi:10.1108/09564230910936832.

Lings, I. (2004). Internal market orientation construct and consequences. Journal of Business Research, 57(4), 405- 413. doi:10.1016/S0148-2963(02)00274-6

Lings, I., \& Greenley, G. (2005). Measuring internal market orientation. Journal of Service Research, 7(3), 290-305. doi:10.1177/1094670504271154

Lings, I., \& Greenley, G. (2009). The impact of internal and external market orientations on firm performance. Journal of Strategic Marketing, 17(1), 41-45. doi:10.1080/09652540802619251

Meyer, J. P., \& Allen, N. J. (1991). A three-component conceptualization of organizational commitment. Human Resource Management Review, 1(1), 61-89. doi:10.1016/10534822(91)90011-Z

Meyer, J. P., \& Allen, N. J. (1997). Commitment in the workplace: Theory, research, and application. London, UK: SAGE Publications, Inc.

Meyer, J. P., Allen, N. J., \& Smith, C. A. (1993). Commitment to organizations and occupations: Extension and test of a three-component conceptualization. Journal of Applied Psychology, 78(4), 538-551. doi:10.1037/0021-9010.78.4.538

Meyer, J., Stanley, D., Herscovitch, L., \& Topolnytsky, L. (2002). Affective, continuance, and normative commitment to the organization: A meta-analysis of antecedents, correlates, and consequences. Journal of Vocational Behavior, 61(1), 20-52. doi:10.1006/jvbe.2001.1842. 
Parasuraman, A., Zeithaml, V. A., \& Berry, L. L. (1998). Servqual: A multiple-item scale for measuring consumer perceived value. Journal of Retailing, 64(1), 12-40.

Pimpakorn, N., \& Patterson, P. G. (2010). Customer-oriented behaviour of front-line service employees: The need to be both willing and able. Australasian Marketing Journal (AMJ), 18(2), 57-65. doi:10.1016/j.ausmj.2010.02.004

Plouffe, C., Bolander, W., Cote, J., \& Hochstein, B. (2016). Does the customer matter most? Exploring strategic frontline employees' influence of customers, the internal business team, and external business partners. Journal of Marketing, 80(1), 106-123. doi:10.1509/jm.14.0192

Schneider, B., \& Smith, D. B. (2004). Personality and Organizations. London, UK: Psychology Press.

Sohail, M. S., \& Jang, J. (2017). Understanding the relationships among internal marketing practices, job satisfaction, service quality and customer satisfaction: An empirical investigation of Saudi Arabia's service employees. International Journal of Tourism Sciences, 17(2), 67-85. doi:10.1080/15980634.2017.1294343

Stock, M. R., Jong, A. D., \& Zacharias, N. A. (2017). Frontline employees’ innovative service behavior as key to customer loyalty: Insights into Fles' resource gain spiral. Journal of Product Innovation Management, 34(2), 223-245. doi:10.1111/jpim.12338

Winsted, K. F. (2000). Service behaviors that lead to satisfied customers. European Journal of Marketing, 34(3/4), 399-417. doi:10.1108/03090560010311920

Yu, Q., Yen, D. A., Barnes, B. R., \& Huang, Y. (2017). Enhancing firm performance through internal market orientation and employee organizational commitment. The International Journal of Human Resource Management, 30(6), 1-24. doi:10.1080/09585192.2017.1380059 